THE ANALYSIS OF RACIAL DISCRIMINATION IN SOLOMON NORTHUP'S 12 YEARS A SLAVE

\author{
AN ARTICLE \\ Submitted in Partial Fulfillment of the Requirements \\ for the Degree of Sarjana Sastra
}
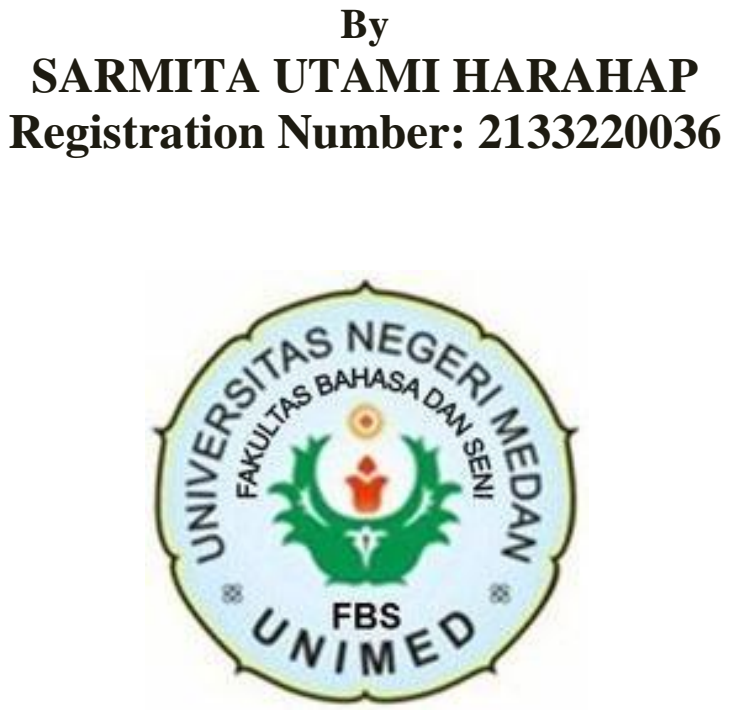

ENGLISH AND LITERATURE DEPARTMENT

FACULTY OF LANGUAGES AND ARTS

STATE UNIVERSITY OF MEDAN

2017 


\title{
ARTIKEL
}

\section{THE ANALYSIS OF RACIAL DISCRIMINATION IN SOLOMON NORTHUP'S 12 YEARS A SLAVE}

\author{
Disusun dan Diajukan oleh: \\ Sarmita Utami Harahap
}

NIM 2133220036

Telah diverifikasi dan dinyatakan memenuhi syarat

untuk diunggah pada jurnal online

Medan, November 2017

Menyetujui

Dosen Pembimbing Skripsi I

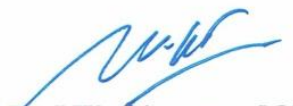

Dr. I Wy Dirgeyasa, M.Hum. NIP. 196305251988032016

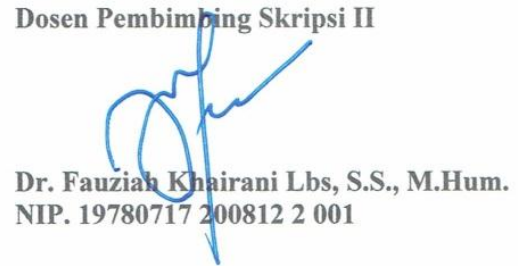

Ka.Program Studi

Sastra Inggris

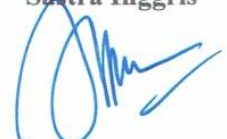

Juli Rachmadani Hasibuan, M.Hum.

NIP. 198207112008012008 


\title{
THE ANALYSIS OF RACIAL DISCRIMINATION IN SOLOMON NORTHUP'S 12 YEARS A SLAVE
}

\author{
*Sarmita Utami Harahap \\ **I Wayan Dirgeyasa \\ **Fauziah Khairani Lubis
}

\begin{abstract}
Utami S. 2133220036. The Analysis of Racial Discrimination in Solomon Northup's 12 Years A Slave. A Thesis. English and Literature Department, Faculty of Languages and Art. State University of Medan. 2017.

The research was focused on racial discrimination faced by the major characters and their resistances in 12 Years A Slave novel. This study was aimed This study was aimed to investigate the racial disrimination and the resistances in the novel. This study was conducted by applying descriptive qualitative method. The source of data was taken from 12 Years A Slave novel. The data are collected by using documentary techniques. Instrument for collecting the data is using documentary sheet. The results of this research were the racial discrimination and resistances happened in 12 Years A Slave. The racial discrimination in this novel happened towards the Black People and all discriminated people do the resistances to make their life better. As Northup is the main character so he got the most discrimination, then in the second position is Patsey and the last is Eliza Berry. Meanwhile the resistances done the most by Northup until he finally got freedom, and Patsey also did it twice and Eliza Berry did it three times. It can be concluded that the three major character who are slaves got discriminated and they did the resistances to save their life, even its only Northup who got the freedom in the end.
\end{abstract}

Keywords : Major Character, Racial Discrimination, Novel

*Graduate status

** Lecturer status 


\section{INTRODUCTION}

\section{Background of the Study}

Literature is a written or printed work which expresses feeling, attitude and life of human in society. So, essentially literature can also be called as a creative act of the writer's imagination in selecting, ordering, and interpretating life experiences in a written work. It also gives lesson from various aspects of human life such as religious, social, moral and also cultural.

The novels entitled 12 Years A Slave is very interesting novel that expresses people and their problem in the society. The problem is dominantly related to racial discrimination that has tremendous effect to the social life of certain people.

Racial discrimination is a differential treatment on the basis of race that disadvantages or a racial group or treatment on the basis of inadequately justified factors other than race that disadvantages a racial group, Blank and Dabady (2004:4).

From the theory above, it is written that racial discrimination disadvantages a certain racial group. But the fact is, its not only disadvatages the certain group but also take away their right as human. This problem is very serious because it always leads destruction to certain human being and the society. People may take it easy because they dont know the destruction those discriminated people got. When those innocent people's human right are stolen by the majorities without any guilty feeling. 
Racism has been part of the American landscape primarily since the European colonization of North America beginning in the 17th century. Many of the Africans brought to America starting in the 17th century arrived as slaves, kidnapped from their homelands in various parts of Africa. A number of them were known to be royalty and literate. African men, women, and children were stripped of their names and identities, forced to "Christianize", whipped, beaten, tortured, and in many cases, lynched or hanged at the whims of their white masters, for whom slavery was key to maintaining their vast properties and land. Families were separated through the process of buying and selling slaves. While not all Africans in America were slaves, a large number were, particularly in the southern states. For those Africans in America who were free, discriminatory laws that barred them from owning property and voting, for example, as well as the belief in the intrinsic inferiority of dark-skinned peoples by the dominant white majority, held them back from full equality in the United States.

Thus, historically the social problem of racism and discrimination ended after the Civil War in 1865. Racism and ethnic discrimination in the United States has been a major issue since the colonial era and the slave era. Legally or socially sanctioned, privileges and rights were given to white Americans that were not granted to Native Americans, African Americans, Asian Americans, and Hispanic and Latino Americans. European Americans were granted exclusive privileges in many matters such as education, voting rights, citizenship, immigration, land 
acquisition, and criminal procedure over periods of time extending from the 17 th century to the 1960 s.

However, non-Protestant immigrants from Europe; particularly Irish people, Poles, and Italians, suffered xenophobic exclusion and other forms of ethnicitybased discrimination in American society, and until the 1960s were not considered white. In addition, Middle Eastern American groups like Jews and Arabs have faced continuous discrimination in the United States, and as a result, some people belonging to these groups do not identify as white. East and South Asians have similarly faced racism in America.

Even in this modern era, in 21 st Century racial discrimination is still felt and experienced by some.. A 2014 study found evidence of racial discrimination in an American rental apartment market. Another study conducted in the Netherlands by Blommaert and published in 2013 found significant levels of discrimination against job applicants with Arabic-sounding names. Even a name could be a reason for someone for being a racist. If we let racial discrimination grow over and over again, it must spread to very little aspect in life and theres gonna be more and more destruction happened in this world.

Those things have become the reason of the writer to choose racial discrimination as the center of this analysis. So that young generation can open up their mind widely not to be a racist. The problem of racial discrimination remains an important factor in shaping contemporary patterns of social and economic 
inequality. So this thing will cause a worse effect if people dont start to deny and solve this problem.

Since there are a lot of cases about racial discrimination, and its big impact towards human life, of course it has been the author's inspiration to make a story about it or he can be an author and also the victim of racial discrimination as the novel that the writer choose, 12 Years A Slave by Solomon Northup. It can be more interesting to find out the form of racial discrimination and also the resistances from the perspective of the victim himself. The main concern of this novel is racial discrimination in the northup's life, where Solomon is being tricked to go to Washington, D.C., where he was kidnapped and sold into slavery in the Deep South.

\section{REVIEW OF LITERATURE}

\section{Racial Discrimination}

Racial Discrimination is a racial group or treatment on the basis of inadequately justified factors other than race that disadvantages a racial group, Blank and Dabady (2004:4). Also defines as the mistreatment of a group of people on the basis of race, color and religion. This problem is very serious because it always leads destruction to certain human being and the society. As

stated by Forman, Racial discrimination has serious consequences, including negatively impacting psychological, physical and work outcomes (2003). 
Barker, (2004 : 170) states that race as a mechanism of social stratification and as a form of human identity is a recent concept in human history. Historical records show that neither the idea nor ideologies associated with race existed before the seventeenth century. In the United States, race became the main form of human identity, and it has had a tragic effect on low-status "racial" minorities and on those people who perceive themselves as of "mixedrace".

2. Resistance

According to Vinthagen and Jhansson (2013:1), resistance is an opposional act. It exists as publicly declared resistance (open revolts, petitions, demonstrations, land invasions, etc.) against : (1) material domination; (2) assertation of worth or desertation of status symbols against status domination; (3) counter-ideologies against ideological domination. The point is those people do the resistance to prevent or even stop the discrimination itself so that they can get a better life.

\section{Character}

Nurgiyantoro, (2007:176) The characters in the story can be divided into some categories based on the point of view taken ; major and minor character, protagonist and antagonist character, round and flat character, dynamic and static character, typical and neutral character.

In 12 Years A S lave novel, there are 16 major characters.

\section{Novel}


Generally, literature can be divided into three genres, they are : poetry, prose and drama. Prose is a genre of literature that portrays people in society. Novel is one of the forms of prose which can be defined as a long fictional story in a book that express the idea of the novelist about man's life experience. Novelist frequently focuses on tensions between individuals and the society (Peck, 1984:102).

5. Synopsis of 12 Years A Slave

Twelve Years a Slave is an 1853 memoir and slave narrative by American Solomon Northup as told to and edited by David Wilson. Northup, a black man who was born free in New York state, details his being tricked to go to Washington, D.C., where he was kidnapped and sold into slavery in the Deep South. He was in bondage for 12 years in Louisiana before he was able to secretly get information to friends and family in New York, who in turn secured his release with the aid of the state. Northup's account provides extensive details on the slave markets in Washington, D.C. and New Orleans, and describes at length cotton and sugar cultivation and slave treatment on major plantations in Louisiana.

In analyzing this novel the approach used is Intrinsic approach emphasizes the analysis on the text while extrinsic approach emphasizes the analysis on the external courses of literary work such as history, social culture, religion, 
psychology, and philosophy. Intrinsic approach would be used by the writer in this research.

Intrinsic approach is an approach that takes the data from literary work itself. The main part of intrinsic approach is based on the text of literary works itself by doing an interpretation and analysis of it. Intrinsic approach however starts the analysis of literary works from the work itself.

The data of the study are the quotations from 12 Years A Slave novel that will be classified based on the racial discrimination and the resistances form. The sentences will be limited into the major characters that experienced being discriminated in the novel.

\section{RESEARCH METHODOLOGY}

This research will be conducted by using the descriptive qualitative method. Strauss $(2003: 2)$ defined that descriptive qualitative method refers to a research explaining the analysis or a hypothesis of a research, the mathematical techniques are of minimal use, although assuredly rudimentary or implicit counting and measuring are usually involved.

The technique of collecting data is documentary technique. In other words, it is simply made into written text as a document about how racial discrimination 
existed in the 12 Years A Slave novel and how the minorities do the resistance against the discrimination done by the majorities.

The data will be analyzed by using descriptive qualitative techniques which is the branch of basic principles of grounded theory developed by Strauss (2003) by the following steps :

1. Identifying the data from the 12 Years A Slave novel that shows the racial discrimination and the resistances they do toward the discrimination itself.

2. Reducing the data which are not relevant.

3. Classifying the data and information.

4. Analyzing and interpreting the data that deals with the racial discrimination

5. Concluding that data that deals with the racial discrimination

\section{RESEARCH FINDINGS AND DISCUSSIONS}

\section{Research findings}

After analyzing data from the statement and narration in the novel, finally writer found the following things :

1. Racial discrimination were exactly happened in Solomon Northup as described in 12 Years A Slave novel. Eventhough he was not born in a slavery, or comes from slave parent, but it could still happened since he was tricked, kidnapped then sold into slavery. 
2. Racial discrimination leads to destruction on Northup's and other slave life. Family seperation also one of the cause of the slavery as could be seen from Northups who seperated from his family, and also Eliza Berry's life, eventhough her children were about to be slaves, but they are seperated. There is also Patsey as the a victim of repeated rapings by Edwin Epps and also of the jealous cruelty of Epps' wife that end by committed suicide.

\section{TABLE A.}

List Of How Many Times Racial Discrimination Happened Toward The Major Character

\begin{tabular}{|c|c|c|}
\hline No & Characters & Racial Discrimination \\
\hline 1. & Northup & 20 times \\
\hline 2. & Eliza Berry & 10 times \\
\hline 3. & Patsey & 11 times \\
\hline
\end{tabular}

\section{TABLE B.}

List Of How Many Times Resistances by The Major Character

\begin{tabular}{|c|c|c|}
\hline No & Characters & Resistance \\
\hline 1. & Northup & 14 times \\
\hline 2. & Eliza Berry & 3 times \\
\hline 3. & Patsey & 2 times \\
\hline
\end{tabular}


From the table above we can see that Northup is the character that dominantly discriminated the most and do the most resistance than another. As Northup is the main character of this novel, he absolutely got discriminated more than the other character, since he appears from the very beginning until the end. Meanwhila Eliza Berry and Patsey state in the second and third position. Because they apppear not from the start till the end, but only in some part. Eventhough that dpesnt mean the discriminaiton they got is not terrible. Eliza Berry is seperated from her children meanwhile Patsey's life ends by suicide and since she always got sexual discrimination from the master.

\section{Discussions}

As stated by Blank and Dabady (2004:4) racial discrimination is a racial group or treatment on the basis of inadequately justified factors other than race that disadvantages a racial group, in 12 Years A Slave it clearly shown how the racial discrimination done by the slave dealer and owner disadvantaged the slave life. They became seperated from family and couldnt live normally since a slave life will depends on what the slave owner did and where the slave dealer sold them to.

In addition as stated by Joe Feagin (2006 : 83), those who were enslaved frequently slought opportunities to secure their liberty and freedom, and their everyday resistances took many forms. The resistances done by slave took many forms, such as action and giving argument. Not all resistances got a positive 
result, there was a slave that did the resistances by giving argument, but what she got was family seperation. Eventhough there was a slave that didn't get the liberty and ended up by death but Northup got his liberties to be a free-man and write a novel about how his life to inspired other to prevent racial discrimination and for those who had been discriminated to fight for his life by doing the resistance.

As the studies by Nazar (2012) he also discussed about racial discrimination. He analyzed about why prejudice became the main concern of racial discrimination in the novel, another aspect that result racial discrimination namely cultural differences, and also about skin-colour as characteristic of racial discrimination as expressed in the novel and about the reason why segregation happening for the weak only. The differences between this research and Nazar's are this research focused on how the racial discrimination happened meanwhile Nazar focused on the reason why the discrimination could happened also Nazar discussed about why segregation happened for the weak while this research focused on how those discriminated people do the resistances to safe their life.

Another research that has similarity with this research is by Susanto (2011) where his research analyzed about the themes of racial discrimination conducted by white against black in America as a reflection of social life in that period. Similar with this research, Susanto also discussed a description about racial discrimination experienced by major character in the novel. 
As the discussion above, it could be conclude that racial discrimination is the crucial issue to be discussed in any kind of literary works especially novel. This research will not only give advantages for the researchers who want to conduct a similar analysis, but also helped people to be an open-minded person to against any form of racial discrimination and also have courage to do the resistance or helped the discriminated people.

After analyzing the novel, the writer went to the conclusions as follows :

1. Racial Discrimination were occured many situations in Northup's life as described in 12 Years A Slave novel from the way they treated the black people as if they were not human that have the same right.

2. The slaves also fight for their right by doing resistances. As resistance was done to get a better life, in the end Northup finally became a free man and he can gather with his family. Resistances were done by the slaves in many some ways such as actions ans also statements.

3. Racial Discrimination leads to human destruction, one of them is slavery as described in 12 Years A Slave. Slavery has brought the dark shroud of humanity as been described in 12 Years A Slave novel. It is forbidden for the slaves to communicate while working. The only one thing is permitted to do, is working.

\section{Suggestions}

There are several suggestions that the writer could give to the readers related to racial discrimination issues, they are : 
1. Racial discrimination is not a simple thing. It causes human desctruction. It doesnt appreciate human as God creature that have right to live safely. So, we must prevent any kind of racial discrimination. Whether it happens individually or in group.

2. For those who have been victims or experienced racial discrimination you should not give up easily and never keep the past thing to do any revenge. Never let the racial discrimination ruin mind, confidence, personality and who we really are as human beings..

3. Racial discrimination is a very important issue that needs to be taken seriously and also as a reminder to people all over the world ; the importance to educate children in their early age so that they dont see or appreciate someone just because of their physical appereance. That the difference among them is not a reason to be separated but to be united instead.

4. Indonesia, as a multi-cultural country, where we come from different religions and also tribes and prmote tolerance so that we.can help avoiding and terminating the destructive effects of racial discrimination.

\section{REFERENCES}

Adytia, R. (2016). The Aspects Of Marxism In Solomon Northup's 12 Years A Slave. Medan. USU Repository.

Barker, C. Sage Dictionary. (2004). London: Sage Publication.

Blank, Rebecca M, Marilyn D. And Constance F. (2004). "Measuring Racial Discrimination Panel On Methods For Assessing Discrimination". Washington, D.C. : The National Academies Press. 
Bowling, B., and Phillips, C. 2002. Racism, Crime and Justice. Larson: Pearson Education.

Dunn. L.C., Dubinin. N.P., Lévi-S, Claude., Leiris, Michael., Klineberg, Otto., Beteille, André., Essien-Udom, E.U., Tjwan, Go Gien., Rex, John., Gluckman, Max. (1975). Race, Science and Society. Paris: The UNESCO Press.

Iwuchukwu, O. 2008. An Introduction to Literature and Literary Criticism. Lagos: National Open University of Nigeria.

Naim, N. (2012). Character Building.Yogyakarta: Ar- Ruzz Media

Nazar, S. (2009). Racial Discrimination Of Sue Monk Kidd's Novel, The Secret Life Of Bees. Medan. USU Repository.

Northup, S. (1853). 12 Years A Slave. Auburn. New York

Nurgiyantoro, B. 1995. Teori Pengkajian Fiksi. Yogyakarta: Gadjah Mada. University Press

Peck, J., and Coyle, M. 1984. Literary Terms and Criticism. London: Ltd Macmillan Education d.Smith

Roberts, E. V. and H. E. Jacobs. 1995. Literature: An Introduction to Reading and Writing. New Jersey: Prentince Hall.

Susanto, A.H. (2011). Racial Discrimination Against Black Main Character Big Boy In A Short Story Big Boy Leaves Home By Richard Wright. Semarang. Diponegoro University.

Teeuw, A. 1983. Membaca dan Menilai Sastra. Jakarta: Pt. Gramedia Pustaka Umum.

Wellek, R. and Austin W. 1977. Theory of Literature. New York: Harcourt Brace Javanovich..

Yip, T, Gilbert C. Gee and David T. Takeuchi. (2008) "Racial Discrimination And Psychological Distress : The Impact Of Ethnic Identity And Age Among Immigrant United States-Born Asian Adults". USA. American Psychological Association. 
Vinthagen S, Johansson A (2013) 'Everyday resistance': Exploration of a Concept and its Theories. Resistance Studies Magazine 1. 